\title{
ANAESTHETIC AGENTS AND TECHNIQUES FOR RENAL HOMOTRANSPLAN'TS
}

\section{David S LeVine, M D , And Robert W Virtue, M D *}

RESUlis OF renal homograft procedures in this clinic have been encouraging ${ }^{1}$ Several inquiries concerning technques used for anaesthesia for these patients have prompted the writung of this note concerning the procedures used for the first 50 patients in the University of Colorado ser ies A pievious ieport dealing largely with para-anaesthetic considerations has been published ${ }^{2}$

Donors of kıdneys were studied to make certain that they were healthy Andesthesia for donors, therefore, did not have to differ from what the anaesthesiologist would ordinarily use for nephrectomy, with three possible variations Fust, this procedure requires considerably more time than standard nephrectomy does, second, the surgeons have consistently requested that the electrocautery be avallable, and third, moderate hypotheimia has been used in several cases A well-standardized hypothermic technique has been developed which allows for these variations ${ }^{34} \mathrm{j}$

Recipıents have all been severely ill Physılogic derangements have included uraemia, fluid and electrolyte imbalance, congestive heart farlure, severe hypertension, hypertensive encephalopathy with convulsions, ietinal haemoirhage and oedema, pulmonary oedema and anaemia Most patiehts have had repeated dialysıs with the artificial kidney, and a few have had a history which included cardiac arrests

Surgery in addition to actual placement of the graft has been frequent Durmg progressive development of su gical and immunological techniques for contiol of the recipient, the greater part of the surgery prior to the transplant has gradually been eliminated Early in the series, however, thymectomy, splenectomy, and nephrectomies were performed in an earlier operation At present the splenectomy, nephrectomy, and implantation of the donor kıdney are performed in one operative procedure Post-tiansplantation pioblems which have required additional andesthesia include drainage of abscess, removal of a rejected kidney, gastrointestinal haemorrhage, and removal of a few kidneys and spleens in separate procedures after implantation of the donor kudneys

The procedures and agents utilized to care for implantation of renal homografts are presented in Table I Procedures and agents employed for pre- and post-transplantation anaesthetics are listed in Table II

Any of several anaesthetic techniques or agents or combinations ther eof may be used successfully The surgeons require d quicl and well-1elaxed patient The reupient requires analgesia The piocedures have been selected to provide these conditions, taking into account the status of each individual patient $A$ single major anaesthetic agent or procedure was employed for only half the

"Division of Anacsthesiology, University of Colorado Medical Center, Denver, Colorido 
TABLE I

Anaesthfia For Renal Homograft

(50 patıents had 56 kidneys implanted in 55 procedures)

\begin{tabular}{|c|c|c|c|c|c|}
\hline $\begin{array}{c}\text { Technique } \\
\text { or agent }\end{array}$ & $\begin{array}{l}\text { As onlv major } \\
\text { technique or } \\
\text { agent }\end{array}$ & $\begin{array}{l}\text { With } \\
\text { halothane }\end{array}$ & $\begin{array}{l}\text { With } \\
\text { flul oxene }\end{array}$ & $\begin{array}{c}\text { With } \\
\text { cyclopropane }\end{array}$ & $\begin{array}{l}\text { With } \\
\text { meperidine and } \\
\text { mitrous oxide }\end{array}$ \\
\hline Spinal & 1 & 11 & 4 & 1 & \\
\hline \multirow{7}{*}{$\begin{array}{l}\text { Continuous } \\
\text { epıdural } \\
\text { Halothane } \\
\text { Fluroxene } \\
\text { Cyclopropane }\end{array}$} & & & & & \\
\hline & 1 & 7 & 4 & & 1 \\
\hline & 21 & & & & \\
\hline & 2 & & & & \\
\hline & 2 & & & & \\
\hline & - & - & - & - & - \\
\hline & 27 & 18 & 8 & 1 & 1 \\
\hline
\end{tabular}

Supplementary drugs admmistered

$\begin{array}{ll}\text { Curare or gallamine } & 31^{*} \\ \text { Prostigmine } & 12 \\ \text { Thiopentone } & 35 \\ \text { Vasopressor } & 37 \\ \text { Succinylcholine } & 16\end{array}$

${ }^{*} 16$ of these also had spinal or epidural

IABLE II

Anaesthitsia for Procedures Related to Renal Homograft (21 patients had 39 procedures)

\begin{tabular}{|c|c|c|c|}
\hline $\begin{array}{l}\text { Technique } \\
\text { or agent }\end{array}$ & $\begin{array}{l}\text { As only major } \\
\text { technique or agent }\end{array}$ & $\begin{array}{l}\text { With } \\
\text { halothane }\end{array}$ & $\begin{array}{l}\text { With } \\
\text { fluroxene }\end{array}$ \\
\hline Spinal & 3 & 4 & \\
\hline Continuous & & & \\
\hline epidural & 1 & 2 & 1 \\
\hline Halothane & 8 & & \\
\hline $\begin{array}{l}\text { Fluroxene } \\
\text { Cyclopropane }\end{array}$ & 8 & & \\
\hline \multirow{3}{*}{ Nitrous oxide } & 1 (analgesia only) & & \\
\hline & -1 & - & - \\
\hline & 32 & 6 & 1 \\
\hline
\end{tabular}

Supplementary drugs admunstered

Curare or gallamme

Prostigmine

Thiopentone

5

Vasopressor

14

Succinylcholine

homograft implantations For the related procedures, four-fifths could be done using a single agent or technique The duration of the surgical manipulation was the most significant factor here, for the related procedures consumed an average of 2 hours and 45 minutes, while the homografts requned an average of 5 hours and 45 minutes of anaesthesia

It must be remembered that electrolyte status of the recipient is certain to be abnormal The artificial kıdney is known to produce a decrease in cholinesterase concentration ${ }^{6}$ so the use of succinylcholine has been avoided in the recently dialysed patient Even so, one patient who received this drug was apnoeic and required artificial respiration for an hour post-surgery $\mathrm{A}$ patient, not involved in transplanation, who received $10 \mathrm{mg}$ of succinylcholme to reheve muscle spasms 
durıng dialysis in our clinic had an immediate cardiac arrest Analysis of his blood revealed a zero cholinesterase level An explanation of the pathophysiology involved may be afforded by the following facts (1) Dialysis decreases the cholinesterase level This would accentuate the effects of succinylcholine (2) Succinylcholıne produces cardiac arrhythmias by some unknown method. ${ }^{78}$ One mechanısm suggested has been a derangement of potassium ion concentration Dialysis which deliberately lowers the potassium ion concentration would allow an already poor situation to deteriorate (3)' Succinylcholine has been shown to increase the plasma level of the potassium ion at the expense of tissue potassium ${ }^{9}$

The possibility of poor excretion by a diseased kidney of barbiturates and relaxants, especially gallamine, has given us some concern The renal homografts, however, have begun normal urinary excretion within minutes of receiving an arterial blood flow almost without exception, so particular caution in this respect has not proved to be imperative

The only recognized complication of anaesthesia in these 94 anaesthetics was in a patient who developed a bilateral pneumothorax immediately postoperatively when an incorrectly oniented ventilation-measuring device acted as a one-way valve, permitting inflation but not deflation Satisfactory recovery followed removal of air

\section{SUMMARY}

1 A compilation of the anaesthetic agents and procedures chosen for patients accepting renal homografts is presented

2 The effect of artificial renal dialysis on the concentration of cholmesterase is emphasized

3 Careful application of any agent or procedure is of more importance than is the choice of any particular anaesthetic

\section{RÉSUMÉ}

Voicı un rapport sur les façons de procéder en anesthésie au cours des 50 premiers cas de greffes rénales humaines à l'Université de Colorado

Les donneurs de reins sont des personnes en santé et, en conséquence, l'anesthésie pour ces cas ne diffère pas de celle que nous employons pour les néphrectomies ordınaires La seule différence est que, chez plusieus malades, nous avons pratıqué une hypothermie légère

Les receveurs ont tous été gravement malades. Nous avons observé de l'urémie, un déséquilıbre de l'eau et des électrolytes, de la défaillance cardıaque congestive, de l'hypertension marquée, de l'encéphalopathie hypertensive, de l'œè̀me et des hémorragies rétıniennes, de l'anémie et de l'œè̀me pulmonaire La plupart des malades avaıent subı des dialyses répétées avec le reın artıficıel et quelques-uns avaient une historre incluant plusieurs arrêts cardiaques La chirurgie a consisté, en plus de la mise en place de la greffe, en une thymectomie, une splénectomie et des néphrectomies A la suite d'une transplantation, les circonstances quı ont nécessité une anesthésıe addıtıonnelle sont un drainage 
d'abcès, l'exérèse d'un rein rejeté, une hémorragie gastro-intestmale et l'exérèse de 1 eins et de rates au cours dopérations différentes après la transplantation rénale Les façons de procéder et les agents employés dans chacun de ces cas sont mentionnées dans les deux tableaux

N'importe laquelle des nombreuses techniques anesthésıques, n'importe lequel des agents ou des associations d'agents peuvent être employés avec succès Les chirurgiens exıgent un malade calme et bien relâché Le receveur a besoin d'analgesıe L'équilibre électrolytıque du receveur est à coup sûr anormal On sait que le rem artıficiel entraîne une dımınution des cholnestérases, c'est pourquor nous nous sommes abstenus de donner de la succinylcholine, aux malades dialysés récemment Nous nous sommes posé des questıons sur la possibilité d'une mauvaise excrétıon des barbiturıques et des myorésolutifs, spécialement la gallamine, par un rein malade Le soin apporté à l'admmıstration d'un agent est plus impoitant que le choix d'un anesthésique en partıculier

\section{REFERENCES}

1 Starzl, $T$ E, Marchioro, T L, Holmes, I $H$, Brittain, $R$ S, Herman, G, Stonington, O G, Knight, I C S, Talmadee, D W, \& Waddell, W R Clinical Problems in Renal Homotransplantation I A M A 187 734 (1964)

Starzl, $T$ E, Marchiono, $T$ L, \& Waddel L, W $R$ The Reversal of Rejection in Human Renal Homografts, with Subsequent Development of Homograft Tolerance Surg, Gynec \& Obst (in press)

2 Vandai, L D, Harrison, J H, Murrax, J E \& Merrill, J P Ariesthetic Aspects of Renal Homotransplantation in Man Anesthesiology 23783 (1962)

3 Blair, E, Swan, $\mathbb{H}$, \& Virtue, $R$ W Clinical Hypothermia A Study of the Icewater Surface Immersion and Short-Wave Diathenny Rewarming Technics Am Surg, 22 869 (1956)

4 Swan, $H$, Virtue, $R$ W, Blount, $S$ G, JR, \& Kircier, $L$ T Hypothermia in Surgery Ann Surg 142382 (1955)

5 Virtue, R W Hypothermic Anesthesid Springfield, Ill Thomas (1955)

6 Holmes, J H, Nakamoto, S, \& Sawyen, $\mathbb{K} \mathrm{C}$, JR Changes in Blood Composition before and after Dialysis with the Kolff Twin Coll Kidney Trans Am Soc for Artificial Internal Organs 416 (1958)

7 Bush, G H, Graham, H A P, Litrlewood, A H M, \& Scotr, L B Danger of Suxamethonım and Endotracheal Intubation in Anaesthesia for Burns Brit Med J 21081 (1962)

8 Williams, $\mathrm{C} H$, Deutsch, $\mathrm{S}$, Linde, $\mathrm{H}$ W, Bullough, J W, \& Dripps, $\mathrm{R}$ D Effects of Intravenously Administered Succinylchohne on Cardiac Rate, Rhythm, and Arterial Blood Pressure in Anesthetzzed Man Ancsthesiology 22947 (1961)

9 Paton, W D M Mode of Action of Neuromuscular Blocking Agents Brit J Anaes $28470(1956)$ 